\title{
Proteolytic Enzymes in Detergents: Evidence of Their Presence through Activity Measurements Based on Electrophoresis
}

\author{
Núria Saperas* and Elsa Fonfría-Subirós \\ Department of Chemical Engineering, Escola Tècnica Superior d'Enginyers Industrials de Barcelona (ETSEIB), \\ Universitat Politècnica de Catalunya (UPC), Av. Diagonal, 647, 08028 Barcelona, Spain
}

Supporting Information

\begin{abstract}
This laboratory exercise uses a problem-based approach to expose students to some basic concepts relating to proteins and enzymes. One of the main applications of enzymes at the industrial level is their use in the detergent market. The students examine a detergent sample to ascertain whether proteolytic enzymes are a component and, if so, which colored detergent granules contain them. A 4hour standard exercise is described that can be easily modified to study a number of conditions that affect enzymatic activity. The students also become familiar with polyacrylamide gel electrophoresis as it is used to visualize the products of enzyme activity.
\end{abstract}

KEYWORDS: Second-Year Undergraduate, Upper-Division Undergraduate, Biochemistry, Laboratory Instruction, Organic Chemistry, Hands-On Learning/ Manipulatives, Consumer Chemistry, Electrophoresis, Enzymes, Proteins/Peptides

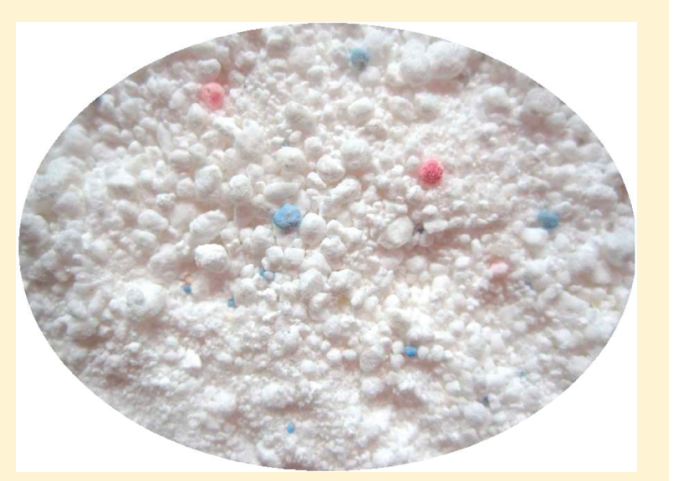

$\mathrm{O}$ ne well-established application of biotechnology is the use of enzymes in detergents. Enzymes are proteins that act as biochemical catalysts and that increase the rate of specific reactions by several orders of magnitude (usually $\geq 10^{6}$ ). Cells cannot function without enzymes, but under controlled conditions, enzymes can work outside of the cell. This discovery led to the development of a growing number of industrial applications of enzymes. One of the main applications of enzymes is their use in detergents (especially laundry and dishwashing detergents) to help in cleaning. Enzymes (especially proteolytic enzymes) are found in products ranging from household laundry and dishwashing detergents to products for contact lens and denture cleaning. However, household laundry is the biggest market.

A measure of success of a laboratory exercise, both in terms of effective learning and motivation, is student engagement. A problembased approach is one way to achieve this, especially if the laboratory relates to familiar industrial or home activities. Thus, a household detergent was chosen to study one of the applications of the catalytic power of enzymes. A number of basic concepts can be examined: the amino acid composition of proteins, the influence of factors such as $\mathrm{pH}$ or temperature on enzyme activity, the effect of denaturation, enzyme inhibition, and so forth. Students also become acquainted with polyacrylamide gel electrophoresis, which is used to see the products of the proteolytic enzyme activity on a protein substrate. This exercise has received positive response from students over the four years it has been performed.

\section{BACKGROUND}

As reviewed elsewhere, ${ }^{1,2}$ the first patent for the use of enzymes in a presoaking product originated in 1913. However, it was not until 1965 that the use of enzymes in detergents came into general use. There was a massive increase in the use of enzymes between 1966 and 1969, but this growth reversed dramatically in 1969-1970 due to hypersensitivity reactions in factory workers handling the dusty enzyme products. The situation was readily understood, and dust-free granulated detergent enzymes were developed. The granulated preparations frequently consist of a core containing the enzyme, surrounded by a coating of inert material that contains a pigment to give it the desired color. The quantity of enzymes in detergents is low $(0.1-1 \%)$.

Proteolytic enzymes (proteases) were the first enzymes to be included in detergents and are still the most used. Proteolytic enzymes degrade proteins by cleaving the peptide bonds, thus assisting in the removal of protein-based stains such as blood and many types of food. Some of these enzymes break all peptide bonds, whereas there are other more specific proteases that only cleave those peptide bonds in which a particular amino acid is involved. ${ }^{3}$ The most widely used protease is subtilisin (named after the bacterium Bacillus subtilis). It is typically obtained by the industrial culture of related Bacillus species. Subtilisin is a nonspecific serine endoprotease, giving preferred cleavage on the carboxyl side of hydrophobic amino acid residues but capable of hydrolyzing most peptide links. It converts its substrates into small, readily soluble fragments that can be removed easily from fabrics. Serine proteases use a catalytic triad (histidine, serine, and aspartic acid) located in the active site of the enzyme. The histidine, with the aid of the proton-withdrawing aspartate, deprotonates the serine hydroxyl, enabling nucleophilic attack on the substrate carbonyl carbon.,

Published: September 26, 2011 
A major challenge for the development of new enzymes or the modification of existing products for detergents is to make them more tolerant to detergent components such as builders, surfactants, and bleaching chemicals. Thus, much effort has been invested to improve subtilisin by means of protein engineering (reviewed in refs 6 and 7).

Although proteases have dominated the detergent market, there is an increasing use of amylases and lipases for the removal of starches and fats. Cellulase has more recently entered the detergent market, and unlike the other enzymes that degrade particular stains, the cellulases act directly on the fabric.

\section{口 EXPERIMENTAL OVERVIEW}

The course is organized as a series of 4-h laboratory exercises that the students do in pairs on a rotational basis. Typically, two to four of these groups work on the same exercise, but each pair is given slightly different work to do. Before the laboratory session, the students read a brief tutorial with the general guidelines of the lab (see Supporting Information). Results of all the groups are discussed in the laboratory and included in a final written report. This encourages cooperative learning.

In the laboratory, a brief introduction is given to explain the principles of the methods, technical details, and protocols. Each group is then given a detergent sample that contains proteolytic enzymes. These enzymes are expected to be in the colored granules of the detergent. A detergent that contains different types of granules (blue and red) was chosen and the groups must identify which granule contains the proteolytic enzymes. The groups are given a protein substrate that will be mixed with an extract prepared with either one of the colored granules. Polyacrylamide gel electrophoresis (PAGE) is used to visualize the effect of the proteolytic digestion. Different conditions can be assayed during the protein digestion if desired (time, different protein substrates, temperature, $\mathrm{pH}$, presence of inhibitors, etc.).

\section{EXPERIMENTAL PROCEDURES}

\section{Detergent}

Although there are a number of detergents in the market that claim enzymes in their formulation, not many specify which particular enzymes are included and in what quantities. Calgonit powder dishwashing detergent was chosen for this laboratory as it specifies the type of enzymes included (proteases and amylases) and has two colored granules (red and blue).

\section{Protein Substrate}

As acetic acid-urea PAGE (AU-PAGE) is used in this laboratory, basic proteins have been chosen as protein substrates. A histone H1-enriched fraction commercialized by Sigma (H5505; histone from calf thymus, Type III-S, lysine-rich fraction) is used as well as protamine (Sigma P4020, protamine sulfate salt from salmon, grade $\mathrm{X}$ ). Protamine is a smaller and more basic protein than histone $\mathrm{H} 1$ as it has only about 32 amino acids (depending on the species) of which $\sim 65 \%$ are arginines. ${ }^{8}$ Both proteins are dissolved in water, either at a concentration of $5 \mathrm{mg} / \mathrm{mL}$ (histone) or $2.5 \mathrm{mg} / \mathrm{mL}$ (protamine). Aliquots are kept at $-20^{\circ} \mathrm{C}$ until used.

\section{Buffer Solutions}

Acetate buffer, Tris- $\mathrm{HCl}$, and glycine- $\mathrm{NaOH}$ buffer have been used for experiments at $\mathrm{pH} 5,7.5$, and 10, respectively. ${ }^{9}$ In all cases, buffers have been prepared at a $10 \times$ concentration $(0.25 \mathrm{M})$.

\section{Protease Inhibitors}

PMSF (phenylmethanesulfonyl fluoride) (Fluka 78830) is prepared at $100 \mathrm{mM}$ in isopropyl alcohol and used at a final concentration of $1 \mathrm{mM}$.

\section{Electrophoresis}

Although SDS-PAGE is the most habitual, we use AU-PAGE because is faster; only one type of gel has to be polymerized and bands can be more quickly visualized. Gels are prepared according to the method of Panyim and Chalkley ${ }^{10}$ as modified by Hurley ${ }^{11}$ (see Supporting Information for details). In these gels, proteins migrate according to their size and charge density. Usually, the gels are run until the tracking dye reaches the middle of the gel (about half an hour) (see the instructor's material in the Supporting Information).

\section{Other Material and Equipment}

Cellophane film, Eppendorf tubes, tweezers, micropipets and tips, vortex mixer, microcentrifuge, and heating baths (only if the effect of temperature is tested).

\section{Protein Digestion and Electrophoretic Analysis}

Using the tweezers, each group places three colored granules from the detergent into an Eppendorf tube. Water, $45 \mu \mathrm{L}$, is added to the tube and the granules are dissolved using a vortex mixer. In some cases, the coating of the granule does not completely dissolve. To avoid these insoluble particles, the tubes are always centrifuged for $3 \mathrm{~min}$ at $10000 \mathrm{rpm}$. The supernatant is separated from the pellet and is used for the protein digestion, which is monitored usually at 2, 20, and $60 \mathrm{~min}$.

The digestion mixture is prepared with enough substrate protein for the time course. If three time points are tested, $12 \mu \mathrm{L}$ of the substrate protein solution is mixed with $6 \mu \mathrm{L}$ of deionized water, $2.1 \mu \mathrm{L}$ of the desired buffer (prepared $10 \times$ ), and $0.9 \mu \mathrm{L}$ of the former supernatant. The tube is left at room temperature (or other temperature if desired). At each of the selected times, $7 \mu \mathrm{L}$ of the digestion is placed in an Eppendorf tube containing $7 \mu \mathrm{L}$ of $2 \times$ electrophoresis sample buffer, which stops the reaction. A protein control is prepared by mixing $4 \mu \mathrm{L}$ of the protein solution with $2.3 \mu \mathrm{L}$ of water, $0.7 \mu \mathrm{L}$ of the $10 \times$ buffer, and $7 \mu \mathrm{L}$ of $2 \times$ electrophoresis sample buffer.

The control sample and the different aliquots from the digestion are loaded onto an AU-PAGE. Electrophoresis is run from the positive to the negative pole at a constant current of $20 \mathrm{~mA}$. When finished, the gel is stained for 5-10 min and then destained. The gel is saved by allowing it to dry between two layers of wet cellophane film.

\section{- HAZARDS}

Care should always be taken when handling any chemicals, and appropriate protection (laboratory coat, safety glasses and gloves) should be worn at all times. The acrylamide monomer is a neurotoxin and a suspected human carcinogen, so care should be taken when preparing polyacrylamide gels. PMSF is harmful by inhalation, ingestion, or contact with the skin or eyes, so care should be taken with this as well.

\section{RESULTS AND DISCUSSION}

A remarkable characteristic of this laboratory is its flexibility. Not only can the presence of proteases be demonstrated and the location in the detergent found, but also a number of different conditions affecting the activity of these enzymes can be tested with minor variations of the general design of the experiment. 

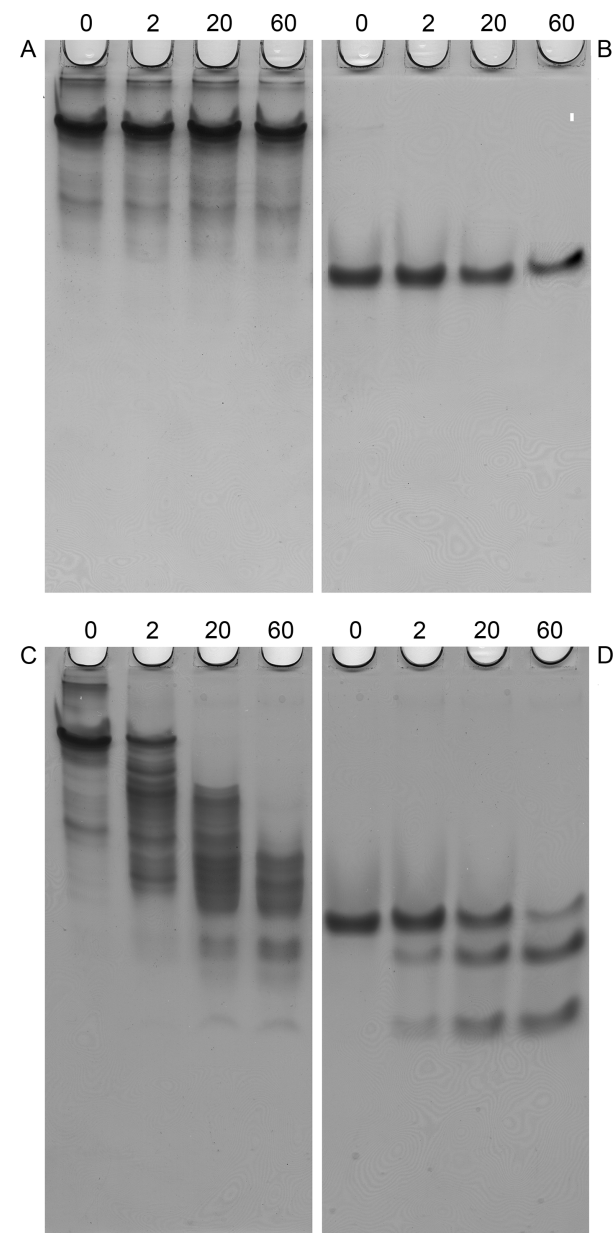

Figure 1. Determination of the presence and location of proteases in the detergent. AU-PAGE of the time course $(0,2,20$, and $60 \mathrm{~min})$ corresponding to the digestion at room temperature of two different protein substrates: (A and C) a histone H1-enriched sample and (B and D) a protamine sample using either the extract obtained from the red granules ( $A$ and $B$ ) or from the blue granules (C and D).

The influence of some of these conditions (type of substrate, time, $\mathrm{pH}$, temperature, and the presence of inhibitors) is discussed.

\section{Presence and Location of Proteases in the Detergent}

Some of the student groups expose their protein substrate to the supernatant extract obtained from the blue granules, while others work with the extract obtained from the red granules. If the reaction is stopped at different times, the effect of time can be evaluated. The results achieved by four pairs of students are shown in Figure 1. This data show the gels obtained after the digestion of two different protein substrates at $\mathrm{pH} 7.5$ using either the supernatant obtained from the red ( $r$-spnt) or from the blue (b-spnt) granules. Panels A and B show the gels corresponding to the digestion for the specified times $(0,2,20$, and $60 \mathrm{~min})$ of the histone $\mathrm{H} 1$-enriched fraction (panel A) and the protamine (panel B) with the r-spnt. Analogously, panels C and D show the gels of the digestions of both proteins with b-spnt for the same times.

Students can easily identify that the blue granules contain the proteases. The gels corresponding to panels A and B show no variation in the mobility of the proteins used as substrate. The bands observed after 2, 20, and 60 min of digestion present the

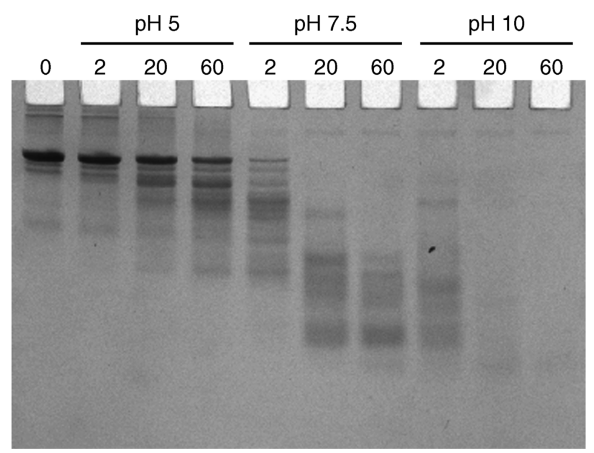

Figure 2. Effect of $\mathrm{pH}$ on the proteolytic activity analyzed by AU-PAGE. Time course $(0,2,20$, and $60 \mathrm{~min})$ corresponding to the digestion of the histone $\mathrm{H} 1$-enriched sample with blue granules carried out at room temperature at $\mathrm{pH} 5, \mathrm{pH} 7.5$, and $\mathrm{pH} 10$.

same migration as the bands at $0 \mathrm{~min}$ due to the absence of any proteolytic enzyme in the r-spnt. The gels obtained after digestion of both protein substrates with the b-spnt (panels C and D) show that the protein is fragmented even after $2 \mathrm{~min}$. As the protein substrates have high positive linear charge densities, the mobility differences observed by AU-PAGE can be mainly attributed to molecular weight differences. As the time course progresses, more smaller, faster moving fragments are found.

Other features can be discussed related both to the protein digestion and the electrophoretic technique. For instance, why protamine presents a greater migration than histone (compare lanes 0 in panels $A$ and $B$ of 1 ), why different proteins present different proteolytic patterns (compare panels C and D of 1 ), or why this electrophoresis is run from the positive to the negative pole can be discussed. It also can be pointed out that this experimental protocol only detects the presence of proteolytic enzymes. Thus, it is not possible to state that there are no enzymes in the red granules, only that no proteolytic enzymes are present in these granules. Possibly the amylases, also claimed to be present in the detergent, are in the red granules.

\section{Variations in the Experiment}

Effect of $\mathrm{pH}$ on the Proteolytic Activity. The same experiment can be done preparing the sample reaction at different $\mathrm{pHs}$ to explore the effect of $\mathrm{pH}$ on the activity of the enzyme. Note that in this case it is important that the same enzymatic extract is used for the different $\mathrm{pH}$ conditions to avoid variations due to differences in the quantity of enzyme because every granule may not contain exactly the same quantity of protease. The results of the experiment using $\mathrm{H} 1$ as protein substrate carried out in acidic ( $\mathrm{pH} 5)$, neutral ( $\mathrm{pH} 7.5)$, and basic $(\mathrm{pH} 10)$ conditions are shown in Figure 2. Only the results obtained with the blue supernatant (the one that contains the proteolytic enzymes) are shown.

The detergent environment is very hostile for proteins, and the proteases used in detergents have to be stable at a high $\mathrm{pH}$. Comparing the results obtained at $\mathrm{pH} 7.5$ with those obtained at $\mathrm{pH} 10$, it is obvious that the protease present in the detergent is still active at $\mathrm{pH} 10$ and that it is more efficient. The digestion progresses more rapidly at $\mathrm{pH} \mathrm{10}$, and after $20 \mathrm{~min}$, almost all of the protein has been digested. On the contrary, when the digestion is performed with the same extract at $\mathrm{pH} 5$, the proteolytic activity drops dramatically. Thus, although there is some fragmentation of the substrate protein, there is little progress with time and even after $60 \mathrm{~min}$ a lot of undigested protein remains. 


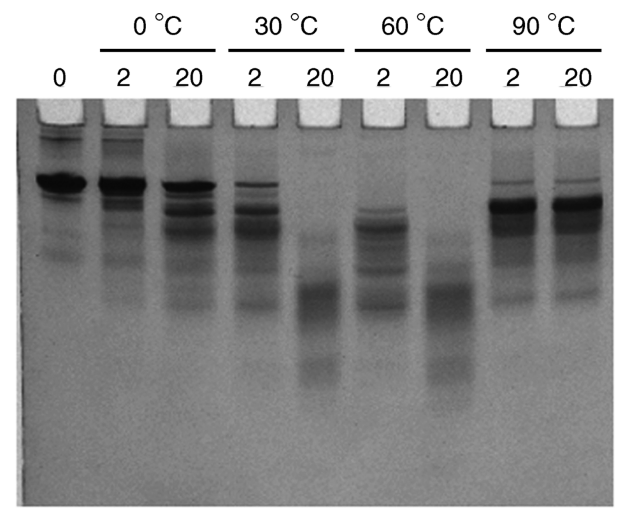

Figure 3. Effect of temperature on the proteolytic activity analyzed by AU-PAGE. Time course $(0,2$, and $20 \mathrm{~min})$ corresponding to the digestion of the histone $\mathrm{H1}$-enriched sample with blue granules at $\mathrm{pH}$ 7.5 and temperatures of $0,30,60$, and $90{ }^{\circ} \mathrm{C}$.

Although this could be attributed to denaturation of the enzyme in this acidic $\mathrm{pH}$, it is more likely due to the protonation state of the catalytic triad (the protonated histidine cannot extract the proton from serine). Control reactions without the enzyme can also be carried out if desired. In this case, no proteolytic activity is observed in any case (data not shown).

Effect of Temperature on the Proteolytic Activity. Another condition that is known to affect chemical reactions is temperature. Different groups of students can use the same granule extract to prepare an identical digestion reaction at different temperatures. The results of four groups working with the extract obtained from the blue granules are shown in Figure 3. Histone $\mathrm{H} 1$-enriched fraction was used as the protein substrate and the reactions were carried out at $\mathrm{pH}$ 7.5. The four temperatures tested were $0,30,60$, and $90{ }^{\circ} \mathrm{C}$ and the reactions were stopped after 2 and $20 \mathrm{~min}$. Although there is some proteolytic activity at $0{ }^{\circ} \mathrm{C}$, it is very low, and only a reduced fragmentation of the protein is observed in the gel. Proteolytic activity increases with temperature: after only $2 \mathrm{~min}$ at $30^{\circ} \mathrm{C}$, most of the protein substrate is fragmented, and after $20 \mathrm{~min}$, all of the protein is digested and the fragments resulting from the more extended digestion are smaller (as reflected by their higher electrophoretic mobility). Proteolysis is even faster at $60{ }^{\circ} \mathrm{C}$ and no intact protein is found after $2 \mathrm{~min}$ (although after $20 \mathrm{~min}$ the fragmentation pattern was similar to that at $30{ }^{\circ} \mathrm{C}$ ). However, when the temperature was increased to $90{ }^{\circ} \mathrm{C}$, the proteases present in the detergent had a limited effect on the protein used as a substrate. Thus, although there was activity during the first $2 \mathrm{~min}$ (as reflected by the decrease of the band corresponding to $\mathrm{H} 1$ and the presence of a number of proteolytic fragments), the activity does not increase and the same electrophoretic pattern is observed after $20 \mathrm{~min}$. This behavior is clearly the result of thermal denaturation of the proteolytic enzyme. Although proteases used in detergents usually have a high thermal stability (note that the proteolytic enzyme work well at $60{ }^{\circ} \mathrm{C}$ ), when temperature is too high, the enzyme loses its conformation and therefore its activity.

Another simple way to check the effect of thermal denaturation is to prepare an extract from blue granules and divide it into two aliquots. If one of the aliquots is used as before and the other aliquot is boiled for $5 \mathrm{~min}$, different results are obtained. In the former, fragmentation of the protein is observed, whereas in the latter, no activity is observed (results not shown). Note

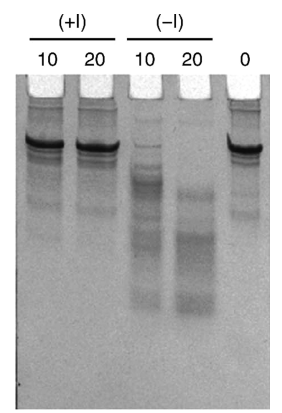

Figure 4. Effect of the presence of protease inhibitors analyzed by AU-PAGE. Time course $(0,10$, and $20 \mathrm{~min})$ corresponding to the digestion of the histone $\mathrm{H} 1$-enriched sample with blue granules at $\mathrm{pH}$ 7.5 and room temperature in the presence $(+\mathrm{I})$ or absence $(-\mathrm{I})$ of $1 \mathrm{mM}$ $\mathrm{PMSF}$ as protease inhibitor.

that before preparing the digestion reaction, the extract should be centrifuged again to eliminate the insoluble material (resulting from the denatured proteins).

Effect of Protease Inhibitors. Although the brand of detergent used in this laboratory exercise gives no information about the specific protease in the formulation, it is likely that it is subtilisin or a related protease. Subtilisin is a nonspecific protease of the serine endopeptidase family ${ }^{12}$ that can be inhibited by PMSF (a known inhibitor of serine peptidases). ${ }^{13}$ This can be tested by using the proteolytic extract obtained from the blue granules to digest histone $\mathrm{H} 1$ in the same way as described but in the presence or absence of PMSF in the reaction mixture. The results obtained after 10 and $20 \mathrm{~min}$ of reaction at room temperature with $(+\mathrm{I})$ or without $(-\mathrm{I})$ the inhibitor PMSF $(1 \mathrm{mM})$ are shown in Figure 4. It can clearly be seen that, in the absence of PMSF, the digestion progresses as always. However, the addition of $1 \mathrm{mM}$ PMSF completely inhibits the activity of the proteolytic enzyme. These results confirm that the enzyme present in the blue granules is a serine protease.

\section{ASSOCIATED CONTENT}

\section{S Supporting Information}

Student handout; notes for the instructor; if SDS-PAGE is preferred to AU-PAGE, the instructor notes include the necessary explanations to carry out this type of electrophoresis as well as the same results presented in Figures 2-4 but analyzed by SDS-PAGE. This material is available via the Internet at http:// pubs.acs.org.

\section{AUTHOR INFORMATION}

\section{Corresponding Author}

*E-mail: nuria.saperas@upc.edu.

\section{ACKNOWLEDGMENT}

This work has been supported in part by grant BFU200910380 from the Ministerio de Ciencia e Innovación, Spain. The authors are very grateful to Alfonso Rodríguez-Galán for his enthusiasm in including this laboratory exercise as part of our course. Thanks are also due to Carolina Ramos and Georgina Sanahuja for their technical help and to Juan A. Subirana and Crisara Abrams for their critical review of the manuscript. 


\section{REFERENCES}

(1) Eriksen, N. Industrial Enzymology; Godfrey, T., West, S., Eds; Macmillan Press LTD: London, 1996; pp 187-200.

(2) Smith, J. E. Biotechnology, 4th ed.; Cambridge University Press: Cambridge, 2004.

(3) Smith, B. J. Methods in Molecular Biology, Vol. 32; Walker, J. M., Ed.; Humana Press: Totowa, NJ, 1994; pp 289-296.

(4) Erez, E.; Fass, D.; Bibi, E. Nature 2009, 459, 371-378.

(5) Wikibooks. Structural Biochemistry. http://en.wikibooks.org/ wiki/Structural_Biochemistry/Enzyme/Catalytic_Triad (accessed Jun 2011).

(6) Bryan, P. Biochim. Biophys. Acta 2000, 1543, 203-222.

(7) Walsh, G. Biochem. Mol. Biol. Educ. 2007, 35, 2-8.

(8) Oliva, R.; Dixon, G. H. Prog. Nucleic Acid Res. Mol. Biol. 1991, 40, 25-94.

(9) Stoll, V. S.; Blanchard, J. S. Methods in Enzymology, Vol 182; Deutscher, M. P., Ed.; Academic Press, Inc.: New York, 1990; pp 24-38.

(10) Panyim, S.; Chalkley, R. Arch. Biochem. Biophys. 1969, 130, 337-346.

(11) Hurley, C. K. Anal. Biochem. 1977, 80, 624-626.

(12) Neidhart, D. J.; Petsko, G. A. Protein Eng. 1988, 2, 271-276.

(13) Fahrney, D. E.; Gold, A. M. J. Am. Chem. Soc. 1963, 85, 997-100. 